\title{
Herpetofauna of Parque Estadual Altamiro de Moura Pacheco: one of the last remnants of seasonal forest in the core region of the Brazilian Cerrado
}

\author{
Werther Pereira Ramalho ${ }^{1,2}$, Daniella Pereira Fagundes Françä ${ }^{3,4}$, Vinicius Guerra ${ }^{2,5}$, \\ Rosy Marciano ${ }^{2,8}$, Nilton Carlos do Vale ${ }^{6}$ \& Hélder Lúcio Rodrigues Silva ${ }^{7}$ \\ 1 Universidade Estadual de Goiás (UEG), Programa de Pós-Graduação em Recursos Naturais do Cerrado (RENAC). Anápolis, G0, Brasil. \\ ORCID: 0000-0002-1049-2307. E-mail: wertherpereira@hotmail.com (corresponding author). \\ ${ }^{2}$ Instituto Boitatá de Etnobiologia e Conservação da Fauna (IBEC). Goiânia, GO, Brasil. \\ 3 Universidade Estadual Paulista (UNESP), Instituto de Biociências, Departamento de Zoologia, Programa de Pós-Graduação em Zoologia. \\ Rio Claro, SP, Brasil. ORCID: 0000-0002-0810-247X. E-mail: moojeni@hotmail.com \\ ${ }^{4}$ Universidade de São Paulo (USP), Museu de Zoologia (MZUSP). São Paulo, SP, Brasil. \\ ${ }^{5}$ Universidade Estadual de Maringá (UEM), Programa de Pós-Graduação em Ecologia de Ambientes Aquáticos Continentais (PEA). \\ Maringá, PR, Brasil. ORCID: 0000-0003-1912-1139. E-mail: vinicius.guerrabatista@gmail.com \\ ${ }^{6}$ Fauna Projetos e Consultoria Ambiental. Goiânia, G0, Brasil. E-mail: nilton@faunaconsultoria.com.br \\ 7 Pontifícia Universidade Católica de Goiás (PUC-G0), Departamento de Biologia. Goiânia, G0, Brasil. E-mail: helderlucio11@gmail.com \\ 8 E-mail: rosy_marciano@hotmail.com
}

\begin{abstract}
Studies in remnants of semi-deciduous seasonal forest of the Cerrado are needed to fill sampling gaps and improve basic knowledge of biodiversity. This study presents data on the herpetofauna of Parque Estadual Altamiro de Moura Pacheco, one of the last protected areas of seasonal forest in the core region of the Brazilian Cerrado. Fourteen sites were sampled between March 2007 and April 2008 using pitfall traps and active searches. A total of 35 anuran species were recorded, most of which were found in hygrophilous environments near forest fragments, open areas and riparian or gallery forest. A total of 29 reptile species were recorded, most of which were found in semi-deciduous forest and riparian or gallery forest. Fourteen of the amphibians and five of the reptiles are endemic to the Cerrado. The richness of amphibians and reptiles found in Parque Estadual Altamiro de Moura Pacheco is regionally representative, with communities typical of forest environments.
\end{abstract}

Key-Words. Semi-deciduous forest; Protected area; Mato Grosso de Goiás; Amphibians; Reptiles.

\section{INTRODUCTION}

The Cerrado Biome comprises a mosaic of vegetation in the central region of the South America with dry open areas, forest remnants along streams and rivers, and dense woodlands (Ab'Sáber, 1983; Ribeiro \& Walter, 2008). Accelerated destruction of natural landscapes in the Cerrado makes it one of the most threatened biomes of the world (Mittermeier et al., 2004). Current estimates show that only $47 \%$ of the Cerrado is covered by its natural vegetation (Beuchle et al., 2015). Since many natural areas have been converted into agriculture and pasture, the creation and maintenance of protected areas is the fastest and most efficient way to conserve species of fauna and flora of the Cerrado (Bensusan, 2006; Françoso et al., 2015). Recent studies indicate that between $5.5 \%$ and $6.5 \%$ of original Cerrado vegetation is maintained by protected areas (Mittermeier et al., 2004;
Françoso et al., 2015). However, the effectiveness and purposes of these units should be the subject of deeper analyses, since protection efficiency is likely dependent on the type, use restriction, governing agency, size and age of the protected area (Paiva et al., 2015).

Landscapes composed of open and forested remnants create mosaics of heterogeneous habitats throughout the Cerrado (Silva et al., 2006). As a consequence, the Cerrado supports a high level of biological diversity, including 209 amphibian species (Valdujo et al., 2012) and 103 squamate reptiles (Nogueira et al., 2011). A significant part of this biodiversity can be found in protected areas, which may hold high species richness, both at local and regional scales (Nogueira et al., 2009; Morais et al., 2012; Santoro \& Brandão, 2014). These areas may be effective for long-term in situ conservation of biodiversity and the maintenance of species' genetic variability (Bensusan, 2006; 
Luque et al., 2012). Thus, knowledge of the species occurring in protected areas is essential for the development of conservation strategies.

Increases in the number of wildlife inventories has improved knowledge regarding amphibians and reptiles, resulting in the expansion of the area of occurrence (range) of many species and descriptions of new species (e.g., Brasileiro \& Haddad, 2015; Vaz-Silva et al., 2015), thus facilitating studies of distribution patterns (e.g., Vasconcelos et al., 2014). However, there are still remains large sampling gaps, most notably in remnants of seasonal semi-deciduous forest in the central region of the Cerrado. This type of forest formation occurs on interfluves and places rich in nutrients, where fallen leaves contribute to increased organic matter in the soil (Ribeiro \& Walter, 2008). Due to their high productivity, these forested areas have been exploited for decades and now are restricted to a few small preserved patches (Moura \& Bucci, 1981). Currently, between $20 \%$ and $60 \%$ of the semi-deciduous forest of the Cerrado has been converted into agriculture and pasture areas, and have suffered from wood extraction and other human impacts (Silva et al., 2006). Given this scenario of degradation and loss of natural habitats, studies on biodiversity in semi-deciduous seasonal forest remnants are of extreme importance, both to fill sampling gaps and to improve basic knowledge regarding the conservation status of species. In this context, the present study pres- ents data about the species richness and composition of the herpetofauna of Parque Estadual Altamiro de Moura Pacheco, one of the last protected areas composed of remnants of semi-deciduous seasonal forest in the core region of the Brazilian Cerrado.

\section{MATERIAL AND METHODS}

\section{Study area}

Parque Estadual Altamiro de Moura Pacheco (PEAMP) is a protected area created to preserve one of the last remnants of seasonal and dry forest in the state of Goiás, Brazil (Fig. 1). The total area of PEAMP is about $32.46 \mathrm{~km}^{2}$, and the predominant vegetation is seasonal semi-deciduous forest, which covers approximately $75.54 \%$ of its extension (Campos \& Batista, 2010). This forest vegetation is characterized by an arboreal strata with an average height of between 15 and $25 \mathrm{~m}$ and canopy cover ranging from 70 to $95 \%$ in the rainy season and $50 \%$ or less in the dry season (Ribeiro \&Walter, 2008). The vegetation of PEAMP also possesses gallery forests and small patches of woody savannah (Cerrado sensu strictu) and forest-like savannah (Cerradão). It is surrounded by landscapes modified for agricultural activities and urban centers. The main watercourse is the João Leite River, a tributary
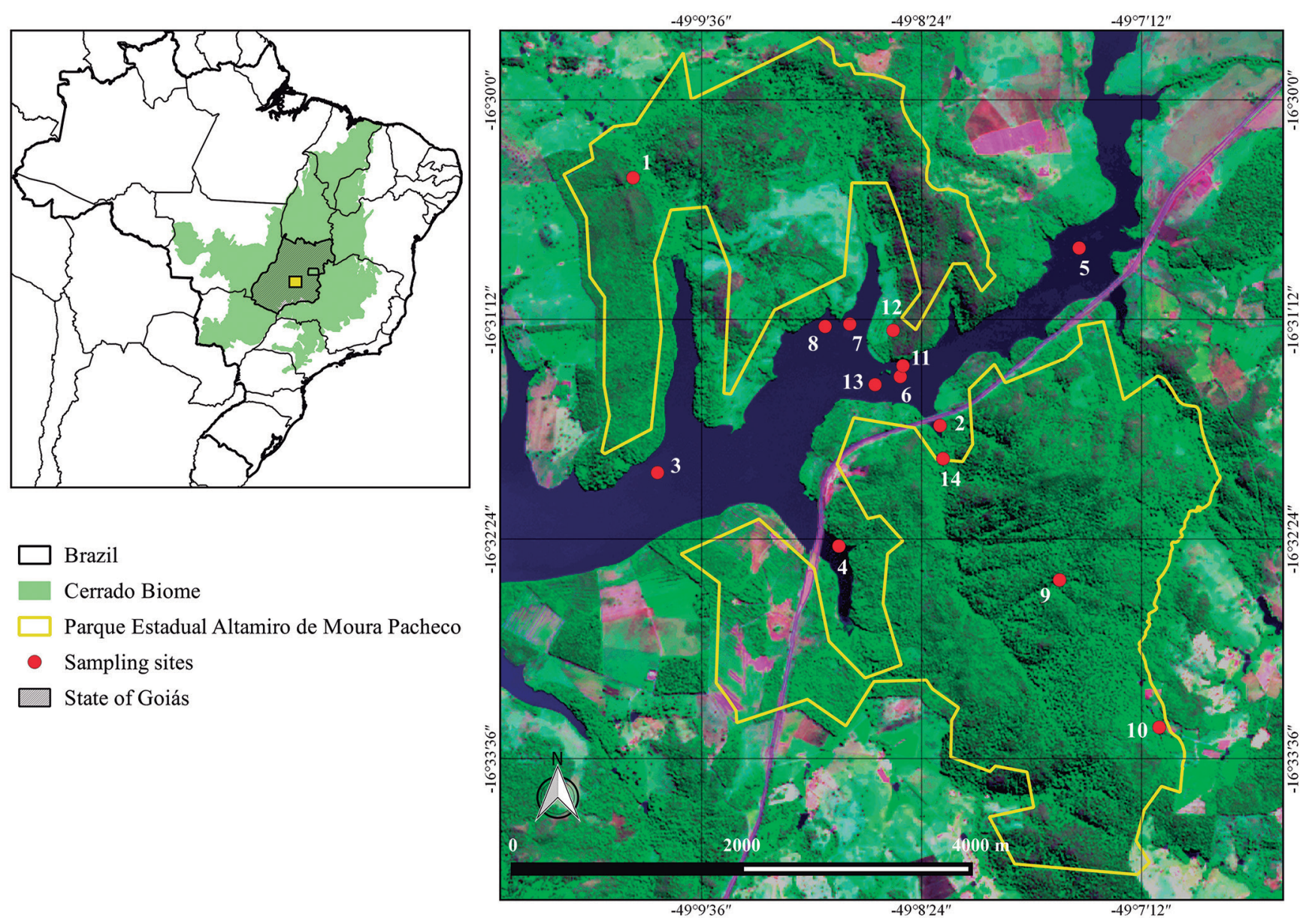

Figure 1. Geographic location of Parque Estadual Altamiro de Moura Pacheco in the state of Goiás, central Brazil. Sampling sites 2-8, 11 and 13 are currently flooded by the João Leite Reservoir. 
Table 1. Sampled sites in Parque Estadual Altamiro de Moura Pacheco, Goiás, Brazil, with sampling methods used, geographic coordinates and type of environments sampled.

\begin{tabular}{cllll}
\hline Site & \multicolumn{1}{c}{ Method } & \multicolumn{1}{c}{ Geographical coordinates } & Environments \\
\hline S1 & Active search, pitfall & $16^{\circ} 30^{\prime} 27.18^{\prime \prime} \mathrm{S}$ & $49^{\circ} 09^{\prime} 59.86^{\prime \prime} \mathrm{W}$ & Gallery forest \\
S2 & Active search, pitfall & $16^{\circ} 31^{\prime} 46.54^{\prime \prime} \mathrm{S}$ & $49^{\circ} 08^{\prime} 20.38^{\prime \prime} \mathrm{W}$ & Hygrophilous near to forest; disturbed areas \\
S3 & Active search, pitfall & $16^{\circ} 32^{\prime} 03.88^{\prime \prime} \mathrm{S}$ & $49^{\circ} 09^{\prime} 51.88^{\prime \prime} \mathrm{W}$ & Seasonal semi-deciduous forest \\
S4 & Active search & $16^{\circ} 32^{\prime} 24.15^{\prime \prime} \mathrm{S}$ & $49^{\circ} 08^{\prime} 55.71^{\prime \prime} \mathrm{W}$ & Hygrophilous near to forest; disturbed areas \\
S5 & Active search & $16^{\circ} 30^{\prime} 50.21^{\prime \prime} \mathrm{S}$ & $49^{\circ} 07^{\prime} 33.83^{\prime \prime} \mathrm{W}$ & Hygrophilous in open areas; palm grove marsh; disturbed areas \\
S6 & Active search, pitfall & $16^{\circ} 31^{\prime} 32.40^{\prime \prime} \mathrm{S}$ & $49^{\circ} 08^{\prime} 32.39^{\prime \prime} \mathrm{W}$ & Riparian forest \\
S7 & Active search, pitfall & $16^{\circ} 31^{\prime} 15.17^{\prime \prime} \mathrm{S}$ & $49^{\circ} 08^{\prime} 48.92^{\prime \prime} \mathrm{W}$ & Seasonal semi-deciduous forest \\
S8 & Active search, pitfall & $16^{\circ} 31^{\prime} 15.95^{\prime \prime} \mathrm{S}$ & $49^{\circ} 08^{\prime} 56.98^{\prime \prime} \mathrm{W}$ & Gallery forest \\
S9 & Active search & $16^{\circ} 32^{\prime} 39.08^{\prime \prime S}$ & $19^{\circ} 07^{\prime} 40.23^{\prime \prime} \mathrm{W}$ & Seasonal semi-deciduous forest; gallery forest \\
S10 & Active search & $16^{\circ} 33^{\prime} 27.41^{\prime \prime} \mathrm{S}$ & $49^{\circ} 07^{\prime} 07.61^{\prime \prime} \mathrm{W}$ & Hygrophilous in open areas; disturbed areas \\
S11 & Active search, pitfall & $16^{\circ} 31^{\prime} 28.85^{\prime \prime S}$ & $49^{\circ} 08^{\prime} 31.51^{\prime \prime} \mathrm{W}$ & Riparian forest \\
S12 & Active search, pitfall & $16^{\circ} 31^{\prime} 17.25^{\prime \prime} \mathrm{S}$ & $49^{\circ} 08^{\prime} 34.70^{\prime \prime} \mathrm{W}$ & Seasonal semi-deciduous forest \\
S13 & Active search & $16^{\circ} 31^{\prime} 35.04^{\prime \prime} \mathrm{S}$ & $49^{\circ} 08^{\prime} 40.64^{\prime \prime} \mathrm{W}$ & Seasonal semi-deciduous forest \\
S14 & Active search & $16^{\circ} 31^{\prime} 57.01^{\prime \prime} \mathrm{S}$ & $49^{\circ} 08^{\prime} 18.84^{\prime \prime} \mathrm{W}$ & Hygrophilous near to forest; seasonal semi-deciduous forest \\
\hline
\end{tabular}

of the Meia Ponte River and one of the main tributaries of the Paranaíba basin. During field sampling (2007 and 2008), the PEAMP had dams and flooded zones covering approximately $0.03 \%$ of its area (Campos \& Batista, 2010). This percentage is currently much higher since part of the vegetation was removed for the insertion of the João Leite Reservoir (between 2009 and 2010), which was constructed to supply water to the municipality of Goiânia (Fig. 1).

The phytophysiognomies sampled in PEAMP were classified as: $\mathrm{DA}=$ disturbed areas; $\mathrm{HF}=$ hygrophilous environments next to forest fragments; $\mathrm{HO}=$ hygrophilous environments in open areas; RF = riparian or gallery forest; SF = seasonal semi-deciduous forest; and VE = palm grove marsh (vereda) (Table 1). The climate of the region is characterized tropical (Aw of Köppen), with two well-defined seasons, one rainy and one dry (Peel et al., 2007). The average monthly temperature is $24.77^{\circ} \mathrm{C}$, with the highest temperatures in September $\left(26.90^{\circ} \mathrm{C}\right)$ and the lowest in June $\left(22.79^{\circ} \mathrm{C}\right)$. The average monthly relative humidity is $59.61 \%$, with highest humidity in December (72.72\%) and the lowest in August (37.67\%). The average monthly rainfall is $137.80 \mathrm{~mm}$, with the greatest rainfall in December $(319.68 \mathrm{~mm})$ and the least in August (2.34 mm) (averages obtained for 2007 to 2016; Brasil, 2018).

\section{Data collection}

Fieldwork was conducted between March 2007 and April 2008 during six field trips (March, May, July and October 2007; January and April 2008), each lasting ten days for a total of 60 sampling days. We use a combination of two field sampling methods: pitfall trap arrays with drift fences (see Ribeiro-Júnior et al., 2011) and visual and auditory searches (Heyer et al., 1994). Eight sites were selected to set up the pitfall trap arrays (Table 1), with each site containing a single array of four 20-liter buckets buried in the soil in a " $\mathrm{Y}$ "-shaped arrangement and interconnected by a 5-meter long, 50-cm high bar- rier. The total sampling effort with this method was approximately 46,080 bucket hours. We conducted active searches along 14 transects of $\sim 1,000$ meters in length (Table 1), during morning (09:00h-12:00h), afternoon (15:00h-18:00h) and night (19:00h-22:00h). Each transect was sampled for approximately one hour by two or three researchers. The total effort resulting from active searches was approximately 504 person hours.

Voucher specimens were collected, anesthetized with $5 \%$ lidocaine, fixed in $10 \%$ formalin and preserved in $70 \%$ alcohol. The compilations available in Frost (2018) and Costa \& Bérnils (2018) were followed for nomenclature for anurans and reptiles, respectively. Voucher specimens were deposited in Coleção Zoológica da Universidade Federal de Goiás (ZUFG) and Coleção de Herpetologia do Centro de Estudos e Pesquisas Biológicas of the Pontíficia Universidade Católica de Goiás (CEPB), Goiânia, Goiás, Brazil (collection permit \#015/2007, process \#5601.01383/2007-4). Species of amphibians and reptiles collected on other occasions by other researchers and placed in the collections of CEPB and ZUFG were also considered in the compilation of the species lists (Appendix 1).

Species distribution patterns and the degree of association with the Cerrado were obtained from information available in Valdujo et al. (2012) for amphibians and Nogueira et al. (2011) for reptiles. Species with occurrences in more than two biomes were considered widely distributed. The conservation status of the species was based on the Red List of Threatened Species of the International Union for Conservation of Nature (IUCN, 2017).

\section{RESULTS}

\section{Amphibians}

We recorded 35 anuran species distributed among seven families (Table 2; Figs. 2-4). The richest families were Hylidae and Leptodactylidae, both with 13 species, followed by Microhylidae (three species), 
Table 2. List of amphibian species recorded in Parque Estadual Altamiro de Moura Pacheco, Goiás, Brazil, and their occurrence, sampling method, and distribution pattern in the Cerrado Biome. Threat Status (TS): NA = Not Evaluated, $\mathrm{LC}=$ Least Concern. Distribution (DS): $E N D=$ Endemic, $W=$ Widely distributed, $C E=C e r r a d 0$, $\mathrm{AF}=$ Atlantic Forest. Habitat: $\mathrm{DA}=$ Disturbed areas, $\mathrm{HF}=$ Hygrophilous environments next to forest fragments, $\mathrm{HO}=$ Hygrophilous environments in open areas, $\mathrm{RF}=$ riparian or gallery forest, $\mathrm{SF}=$ Seasonal semi-deciduous forest, and VE = palm grove marsh (vereda). Method: $A S=$ Active search, $\mathrm{PT}=$ Pitfall trap.

\begin{tabular}{|c|c|c|c|c|}
\hline Family/Species & TS & DS & Habitat & Method \\
\hline \multicolumn{5}{|l|}{ Anura } \\
\hline \multicolumn{5}{|l|}{ Bufonidae } \\
\hline Rhinella sebbeni Vaz-Silva, Maciel, Bastos, \& Pombal, 2015 & NA & END & SF & AS/PT \\
\hline Rhinella diptycha (Cope, 1862) & $\mathrm{LC}$ & W & $\mathrm{HO}, \mathrm{HF}, \mathrm{SF}, \mathrm{VE}$ & AS/PT \\
\hline \multicolumn{5}{|l|}{ Craugastoridae } \\
\hline Barycholos ternetzi (Miranda-Ribeiro, 1937) & $\mathrm{LC}$ & END & SF, RF & AS/PT \\
\hline \multicolumn{5}{|l|}{ Odontophrynidae } \\
\hline Proceratophrys goyana (Miranda-Ribeiro, 1937) & $\mathrm{LC}$ & END & SF, RF & AS/PT \\
\hline Odontophrynus cultripes Reinhardt \& Lütken, 1862 & $\mathrm{LC}$ & END & SF, RF & AS/PT \\
\hline \multicolumn{5}{|l|}{ Hylidae } \\
\hline Boana albopunctata (Spix, 1824) & $\mathrm{LC}$ & W & $\mathrm{DA}, \mathrm{HF}, \mathrm{HO}, \mathrm{VE}$ & AS \\
\hline Boana lundii (Burmeister, 1856) & $\mathrm{LC}$ & END & $H F$, RF, VE & AS \\
\hline Boana paranaiba (Carvalho, Giaretta, \& Facure, 2010) & $\mathrm{LC}$ & END & HF & AS \\
\hline Boana raniceps (Cope, 1862) & $\mathrm{LC}$ & W & $\mathrm{HF}, \mathrm{HO}, \mathrm{RF}, \mathrm{VE}$ & AS \\
\hline Dendropsophus cruzi (Pombal \& Bastos, 1998) & $\mathrm{LC}$ & END & $\mathrm{HF}, \mathrm{HO}, \mathrm{RF}$ & AS \\
\hline Dendropsophus minutus (Peters, 1872) & $\mathrm{LC}$ & W & $\mathrm{HF}, \mathrm{HO}, \mathrm{VE}$ & AS \\
\hline Dendropsophus nanus (Boulenger, 1889) & $\mathrm{LC}$ & W & $\mathrm{DA}, \mathrm{HF}, \mathrm{HO}$ & AS \\
\hline Dendropsophus rubicundulus (Reinhardt \& Lütken, 1862"1861") & $\mathrm{LC}$ & CE, AF & $\mathrm{HF}, \mathrm{HO}$ & AS \\
\hline Pseudis bolbodactyla Lutz, 1925 & $\mathrm{LC}$ & $\mathrm{CE}, \mathrm{AF}$ & $\mathrm{HF}, \mathrm{HO}, \mathrm{VE}$ & AS \\
\hline Scinax constrictus Lima, Bastos, \& Giaretta, 2005 & $\mathrm{LC}$ & END & $\mathrm{HF}, \mathrm{HO}$ & AS \\
\hline Scinax fuscomarginatus (Lutz, 1925) & $\mathrm{LC}$ & W & $\mathrm{HF}, \mathrm{HO}$ & AS \\
\hline Scinax aff. fuscovarius & - & - & $\mathrm{DA}, \mathrm{HF}, \mathrm{HO}$ & AS \\
\hline Trachycephalus typhonius (Linnaeus, 1758) & LC & W & $\mathrm{DA}, \mathrm{HF}, \mathrm{SF}$ & AS \\
\hline \multicolumn{5}{|l|}{ Phyllomedusidae } \\
\hline Pithecopus hypochondrialis (Daudin, 1800) & $\mathrm{LC}$ & END & $\mathrm{HO}, \mathrm{HF}, \mathrm{VE}$ & AS \\
\hline \multicolumn{5}{|l|}{ Leptodactylidae } \\
\hline Adenomera aff. hylaedactyla & - & - & RF, SF, DA & AS \\
\hline Leptodactylus fuscus (Schneider, 1799) & $\mathrm{LC}$ & W & $\mathrm{HO}, \mathrm{HF}, \mathrm{DA}$ & AS \\
\hline Leptodactylus labyrinthicus (Spix, 1824) & $\mathrm{LC}$ & W & $\mathrm{DA}, \mathrm{HF}, \mathrm{HO}, \mathrm{SF}, \mathrm{RF}$ & AS \\
\hline Leptodactylus latrans (Steffen, 1815) & $\mathrm{LC}$ & W & $\mathrm{DA}, \mathrm{HF}, \mathrm{HO}, \mathrm{RF}$ & AS \\
\hline Leptodactylus mystaceus (Spix, 1824) & $\mathrm{LC}$ & W & RF, VE & AS \\
\hline Leptodactylus mystacinus (Burmeister, 1861) & $\mathrm{LC}$ & $C E, A F$ & $\mathrm{HO}, \mathrm{SF}, \mathrm{RF}$ & AS/PT \\
\hline Leptodactylus podicipinus (Cope, 1862) & $\mathrm{LC}$ & W & $\mathrm{HF}, \mathrm{HO}, \mathrm{SF}, \mathrm{RF}, \mathrm{VE}$ & AS/PT \\
\hline Leptodactylus gr. melanonotus & - & - & $\mathrm{HF}, \mathrm{HO}$ & AS \\
\hline Physalaemus atim Brasileiro \& Haddad, 2015 & NA & END & HF & AS/PT \\
\hline Physalaemus centralis Bokermann, 1962 & $\mathrm{LC}$ & END & $\mathrm{HO}, \mathrm{HF}$ & AS/PT \\
\hline Physalaemus cuvieri Fitzinger, 1826 & $\mathrm{LC}$ & W & $\mathrm{DA}, \mathrm{HF}, \mathrm{HO}, \mathrm{SF}, \mathrm{RF}$ & AS/PT \\
\hline Physalaemus nattereri (Steindachner, 1863) & $\mathrm{LC}$ & END & $\mathrm{HO}, \mathrm{HF}$ & AS \\
\hline Pseudopaludicola facureae Andrade \& Carvalho, 2013 & NA & END & $\mathrm{HO}$ & AS \\
\hline \multicolumn{5}{|l|}{ Microhylidae } \\
\hline Chiasmocleis albopunctata (Boettger, 1885) & $\mathrm{LC}$ & END & SF, RF & AS/PT \\
\hline Elachistocleis cesarii (Miranda-Ribeiro, 1920) & $\mathrm{LC}$ & $\mathrm{CE}, \mathrm{AF}$ & $\mathrm{HF}, \mathrm{HO}$ & AS \\
\hline Dermatonotus muelleri (Boettger, 1885) & $\mathrm{LC}$ & W & $\mathrm{HF}, \mathrm{HO}$ & PT \\
\hline
\end{tabular}

Bufonidae and Odontophrynidae (two species each), and Craugastoridae and Phyllomedusidae (one species each). Most species were recorded during active searches (34 species), with 23 being exclusively encountered by this method. Twelve species were recorded using pitfall traps, with Dermatonotus muelleri being exclusively sampled by this method (Table 2).

The majority of amphibian species were recorded in hygrophilous environments near forest fragments (26 species), open areas (24 species) and riparian or gallery forests (14 species). Twelve species were recorded in seasonal semi-deciduous forest, and nine in disturbed areas and palm grove marsh. Fourteen species are endemic to the Cerrado and four occur in Cerrado and Atlantic Forest, while the remaining 14 species are widely distributed. None of the species are considered at any level of threat with most being classified as Least Concern, while three have yet to be evaluated (Table 2).

\section{Reptiles}

We recorded 29 reptile species distributed among 13 families of two orders (Table 3; Figs. 5 and 6). For 


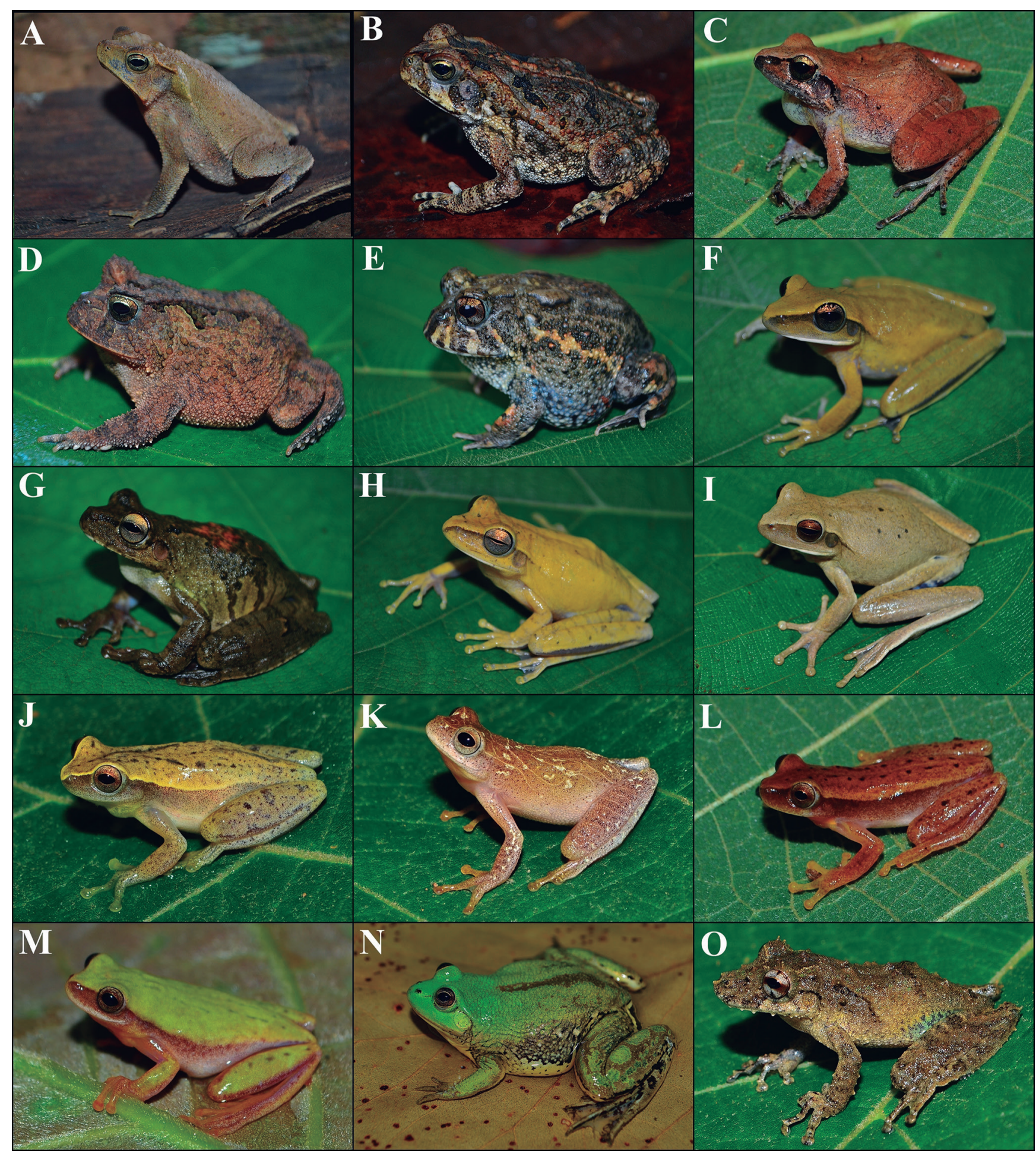

Figure 2. Species of anurans recorded in Parque Estadual Altamiro de Moura Pacheco, state of Goiás, central Brazil: (A) Rhinella sebbeni, (B) Rhinella diptycha, (C) Barycholos ternetzi, (D) Proceratophrys goyana, (E) Odontophrynus cultripes, (F) Boana albopunctata, (G) Boana lundii, (H) Boana paranaiba, (I) Boana raniceps, (J) Dendropsophus cruzi, (K) Dendropsophus minutus, (L) Dendropsophus nanus, (M) Dendropsophus rubicundulus, (N) Pseudis bolbodactyla, (0) Scinax constrictus.

Squamata, the richest families were Dipsadidae (10 species) and Boidae (three species); five other families (Mabuyidae, Tropiduridae, Teiidae, Amphisbaenidae and Viperidae) were represented by two species, and four families (Gekkonidae, Dactyloidae, Anguidae and Colubridae) by one species. Testudines were represented by one species of Chelidae and one of Testudinidae (Table 3). Most reptile species were recorded during active searches (27 species), with 22 being exclusively en- countered by this method. We recorded five species using pitfall traps, with no species being exclusively found by this method. The species Amphisbaena anaemariae and Atractus albuquerquei were included from secondary data (specimens housed in scientific collection - CEPB) (Table 3).

The majority of species were recorded in seasonal semi-deciduous forest (20 species) and riparian or gallery forests (16 species). Thirteen species were recorded in 


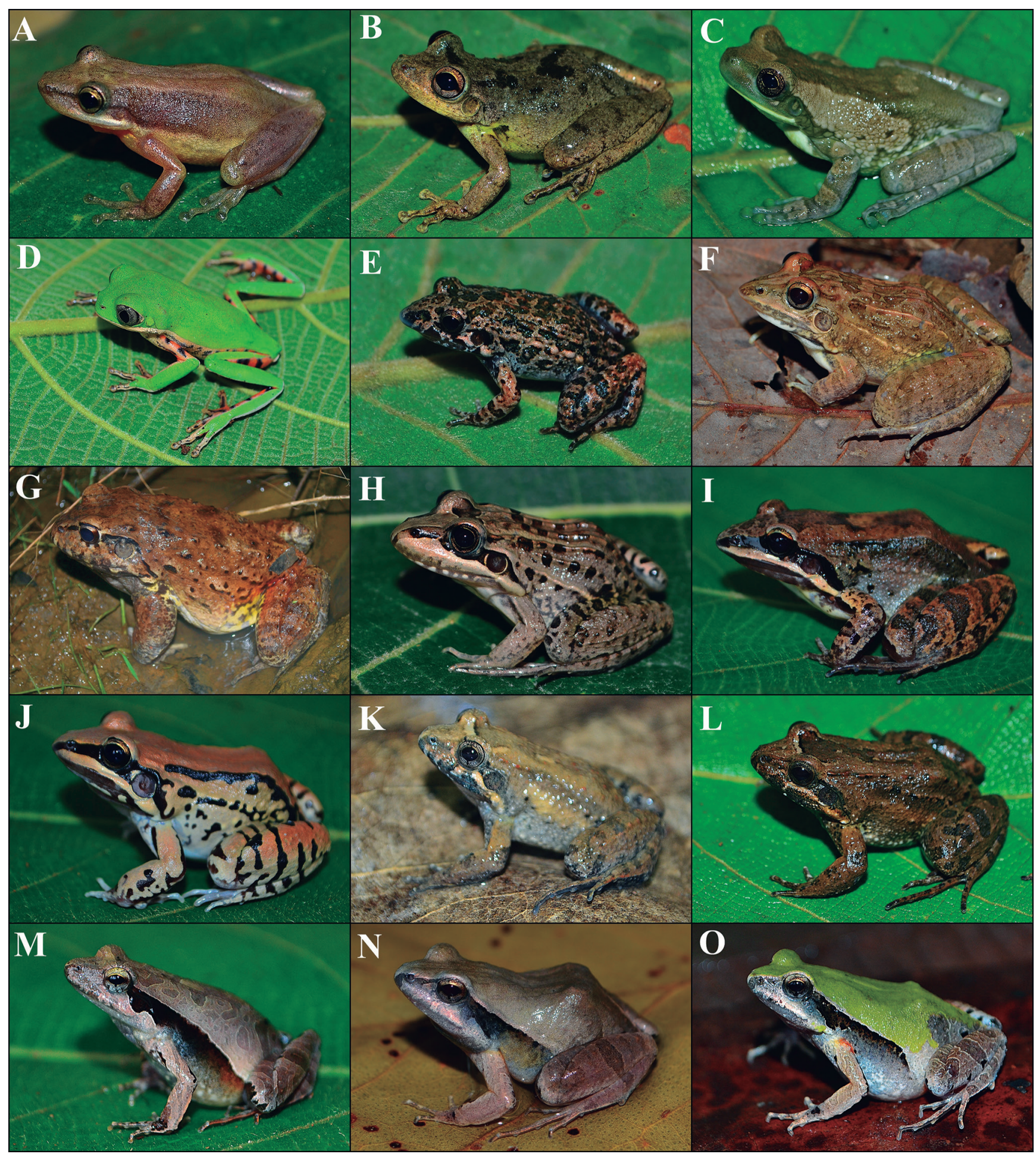

Figure 3. Species of anurans recorded in Parque Estadual Altamiro de Moura Pacheco, state of Goiás, central Brazil: (A) Scinax fuscomarginatus, (B) Scinax aff. fuscovarius, (C) Trachycephalus typhonius, (D) Pithecopus hypochondrialis, (E) Adenomera aff. hylaedactyla, (F) Leptodactylus fuscus, (G) Leptodactylus labyrinthicus, (H) Leptodactylus latrans, (I) Leptodactylus mystaceus, (J) Leptodactylus mystacinus, (K) Leptodactylus podicipinus, (L) Leptodactylus gr. melanonotus, (M) Physalaemus atim, (N) Physalaemus centralis, (0) Physalaemus cuvieri.

disturbed areas and five in hygrophilous environments. Most reptile species (23 species) are widely distributed among the Brazilian biomes, while five are endemic to the Cerrado, one occurring in Cerrado and Atlantic Forest and one occurring in Cerrado and Amazon Rainforest. None of the species are considered at any level of threat; however, the majority has yet to have their conservation status evaluated (Table 3).

\section{DISCUSSION}

\section{Amphibians}

The species richness of amphibians found in PEAMP was similar to that of other localities with a predominance of open vegetation (Kopp et al., 2010; Ramalho et al., 2014; Santoro \& Brandão, 2014) and Cerrado forests 

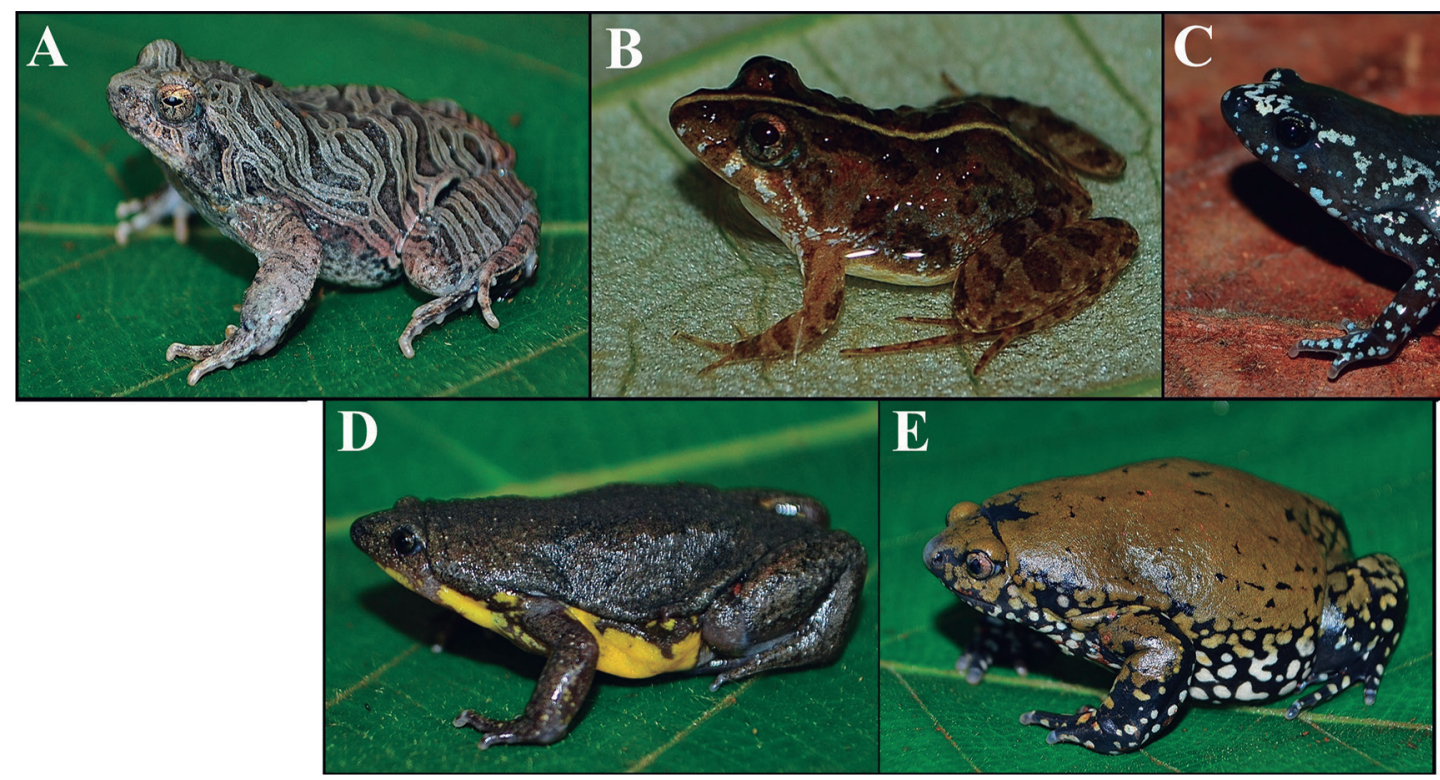

Figure 4. Species of anurans recorded in Parque Estadual Altamiro de Moura Pacheco, state of Goiás, central Brazil: (A) Physalaemus nattereri, (B) Pseudopaludicola facureae, (C) Chiasmocleis albopunctata, (D) Elachistocleis cesarii, (E) Dermatonotus muelleri.

(Morais et al., 2012; Melo et al., 2013). This high richness testifies to the importance of the area for species preservation, especially since it is located close to regions of intense urban development.

The predominance of species from the families Hylidae and Leptodactylidade is a common pattern in the Neotropical Region (Duellman, 1999; Wiens et al., 2011), including studies performed close to PEAMP (Campos \& Vaz-Silva, 2010; Morais et al., 2012; Santos et al., 2014), thus indicating that the sampling methods allowed the recording of species with different ecological requirements (Lynch, 2005). The active search method was more effective than pitfall traps for anuran sampling. However, complementary sampling methods need to be considered since some fossorial species and/or species with explosive breeding (e.g., D. muelleri) are more difficult to find using observational sampling methods.

Although we recorded many species that are considered habitat generalists (e.g., Boana albopunctata, $B$. raniceps, Leptodactylus labyrinthicus, L. podicipinus and Physalaemus cuvieri), none of them occurred in all of the sampled environments. The majority of anurans were found in hygrophilous environments, where Boana paranaiba and Physalaemus atim were found exclusively next to forest fragments, while Pseudopaludicola facureae is typical of open areas. Seasonal semi-deciduous, riparian and gallery forests also possessed several exclusive species, such as Rhinella sebbeni, Barycholos ternetzi, Proceratophrys goyana, Odontophrynus cultripes, Leptodactylus mystaceus and Chiasmocleis albopunctata. Other species seem to depend on waterbodies with forest cover, such as Boana lundii, B. paranaiba and P. atim. The differing preferences among some species for open or forest environments indicates spatial segregation (Gambale et al., 2014; Santos et al., 2014; Dória et al., 2015).

A significant part of the anuran richness found (40\%) is endemic to the Cerrado Biome, where some were re- corded exclusively in forest environments (e.g., R. sebbeni, B. ternetzi, P. goyana, O. cultripes, C. albopunctata). Among these, $P$. atim and $R$. sebbeni were recently described (Brasileiro \& Haddad, 2015; Vaz-Silva et al., 2015), and thus information about their natural history and geographic distribution are lacking, making the assessment of their true conservation status difficult (Morais et al., 2018). Research efforts should be directed towards filling the knowledge gaps for these species, including information about their ecology, natural history and distribution (Guerra et al., 2018). Non-evaluated species represent taxonomic uncertainty (Scinax aff. fuscovarius, Adenomera aff. hylaedactyla and Leptodactylus gr. melanonotus) or are still under evaluation because they have recently been described (e.g., P. facureae). Nonetheless, none of the species are included threat categories.

\section{Reptiles}

The reptile richness found in PEAMP was similar to that of other localities with a predominance of forest environments in the core region of the biome (Morais et al., 2012; Oda et al., 2017); however, it can still be considered low when compared to regions with open vegetation types (Recoder \& Nogueira, 2007; Valdujo et al., 2009; Recoder et al., 2011). Therefore, although the richness of reptiles is within that expected for Cerrado areas, which varies from 15 to 70 species (Costa et al., 2007), the finding confirms a pattern of greater richness in open environments in the biome (Nogueira et al., 2005, 2009).

The predominance of species from the family Dipsadidae is a common pattern often for the Neotropical Region (Cadle \& Greene, 1993; Costa \& Bérnils, 2018). This family includes snakes from different ecological groups (Vidal et al., 2010), and is the richest snake family in the Neotropical Region (Uetz et al., 2018). Other squamate families were represented by few species, cor- 
Table 3. List of reptile species recorded in Parque Estadual Altamiro de Moura Pacheco, Goiás, Brazil, and their occurrence, sampling method, and distribution pattern in the Cerrado Biome. Threat status (TS): $N A=$ Not Evaluated, $L C=$ Least Concern. Distribution (DS): $E N D=$ Endemic, $W=$ Widely distributed, $C E=C$ errado, $\mathrm{AF}=$ Atlantic Forest. Habitat: $\mathrm{DA}=$ Disturbed areas, $\mathrm{HF}=$ Hygrophilous environments next to forest fragments, $\mathrm{HO}=$ Hygrophilous environments in open areas, $\mathrm{RF}=$ riparian or gallery forest, and SF = Seasonal semi-deciduous forest. Method: $\mathrm{AS}=$ Active search, $\mathrm{SC}=$ Scientific collection, $\mathrm{PT}=$ Pitfall trap.

\begin{tabular}{|c|c|c|c|c|}
\hline Family/Species & TS & DS & Habitat & Method \\
\hline \multicolumn{5}{|l|}{ Testudines } \\
\hline \multicolumn{5}{|l|}{ Testudinidae } \\
\hline Chelonoidis carbonarius (Spix, 1824) & NA & W & SF, RF & AS \\
\hline \multicolumn{5}{|l|}{ Chelidae } \\
\hline Phrynops geoffroanus (Schweigger, 1812) & NA & W & $\mathrm{DA}, \mathrm{HF}, \mathrm{RF}$ & AS \\
\hline \multicolumn{5}{|l|}{ Squamata } \\
\hline \multicolumn{5}{|l|}{ Sauria } \\
\hline \multicolumn{5}{|l|}{ Gekkonidae } \\
\hline Hemidactylus mabouia (Moreau De Jonnès, 1818) & NA & W & $\mathrm{DA}, \mathrm{SF}$ & AS \\
\hline \multicolumn{5}{|l|}{ Mabuyidae } \\
\hline Copeoglossum nigropunctatum (Spix, 1825) & NA & W & SF, DA, RF & AS/PT \\
\hline Notomabuya frenata (Cope, 1862) & NA & W & SF, RF & AS \\
\hline \multicolumn{5}{|l|}{ Dactyloidae } \\
\hline Norops brasiliensis (Vanzolini \& Williams, 1970) & NA & END & SF & AS \\
\hline \multicolumn{5}{|l|}{ Tropiduridae } \\
\hline Tropidurus oreadicus Rodrigues, 1987 & NA & $C E, A M$ & SF, DA, RF & AS \\
\hline Tropidurus torquatus (Wied-Neuwied, 1820) & $\mathrm{LC}$ & CE, AF & SF, DA & AS/PT \\
\hline \multicolumn{5}{|l|}{ Anguidae } \\
\hline Ophiodes aff. striatus & - & - & RF & AS \\
\hline \multicolumn{5}{|l|}{ Teiidae } \\
\hline Ameiva ameiva ameiva (Linnaeus, 1758) & NA & W & SF, DA, RF & AS/PT \\
\hline Salvator merianae Duméril \& Bibron, 1839 & $\mathrm{LC}$ & W & $\mathrm{SF}, \mathrm{DA}, \mathrm{HO}, \mathrm{RF}$ & AS/PT \\
\hline \multicolumn{5}{|l|}{ Amphisbaenia } \\
\hline \multicolumn{5}{|l|}{ Amphisbaenidae } \\
\hline Amphisbaena alba Linnaeus, 1758 & $\mathrm{LC}$ & W & DA & AS \\
\hline Amphisbaena anaemariae Vanzolini, 1997 & NA & END & - & SC \\
\hline \multicolumn{5}{|l|}{ Serpentes } \\
\hline \multicolumn{5}{|l|}{ Boidae } \\
\hline Boa constrictor amarali (Stull, 1932) & NA & W & $\mathrm{DA}, \mathrm{SF}, \mathrm{RF}$ & AS \\
\hline Epicrates crassus Cope, 1862 & NA & END & SF, RF & AS \\
\hline Eunectes murinus (Linnaeus, 1758) & NA & W & RF & AS \\
\hline \multicolumn{5}{|l|}{ Colubridae } \\
\hline Spilotes pullatus pullatus (Linnaeus, 1758) & NA & W & SF, RF & AS \\
\hline \multicolumn{5}{|l|}{ Dipsadidae } \\
\hline Apostolepis albicollaris Lema, 2002 & NA & END & SF & AS \\
\hline Atractus albuquerquei Cunha \& Nascimento, 1983 & $\mathrm{LC}$ & W & - & SC \\
\hline Erythrolamprus reginae macrosoma (Amaral, 1935) & NA & W & $\mathrm{HF}, \mathrm{SF}, \mathrm{RF}$ & AS \\
\hline Hydrodynastes gigas (Duméril, Bibron \& Duméril, 1854) & NA & W & RF & AS \\
\hline Oxyrhopus petolarius digitalis (Reuss, 1834) & NA & W & SF, RF & AS \\
\hline Oxyrhopus guibei Hoge \& Romano, 1978 & NA & W & SF & AS \\
\hline Philodryas olfersii (Lichtenstein, 1823) & NA & W & SF & AS \\
\hline Sibynomorphus mikanii mikanii (Schlegel, 1837) & NA & W & DA & AS \\
\hline Taeniophallus occipitalis (Jan, 1863) & NA & W & DA & AS \\
\hline Xenodon merremii (Wagler, 1824) & NA & W & SF & AS \\
\hline \multicolumn{5}{|l|}{ Viperidae } \\
\hline Bothrops moojeni Hoge, 1966 & NA & END & $\mathrm{DA}, \mathrm{HO}, \mathrm{HF}, \mathrm{SF}, \mathrm{RF}$ & AS/PT \\
\hline Crotalus durissus collilineatus Amaral, 1926 & $\mathrm{LC}$ & W & SF, DA & AS \\
\hline
\end{tabular}

roborating what has been found in other Cerrado areas (França \& Braz, 2013; Oda et al., 2017; Rios et al., 2017). Interestingly, families composed of species common in open phytophysiognomies of the Cerrado, such as those of Gymnophthalmidae, as well as some other lizard (e.g., Ameivula ocellifera) and snake (e.g., Bothrops pauloensis) species typical of open environments, were not found. The absence or rarity of these species seems to differen- tiate the structure of the reptile community of PEAMP from other nearby localities with a predominance of open environments.

The majority of reptile species was associated with forest environments and many were found exclusively in these environments, including chelonians (e.g., Chelonoidis carbonarius), lizards (e.g., Notomabuya frenata, Ophiodes aff. striatus) and snakes (e.g., Epicrates cras- 

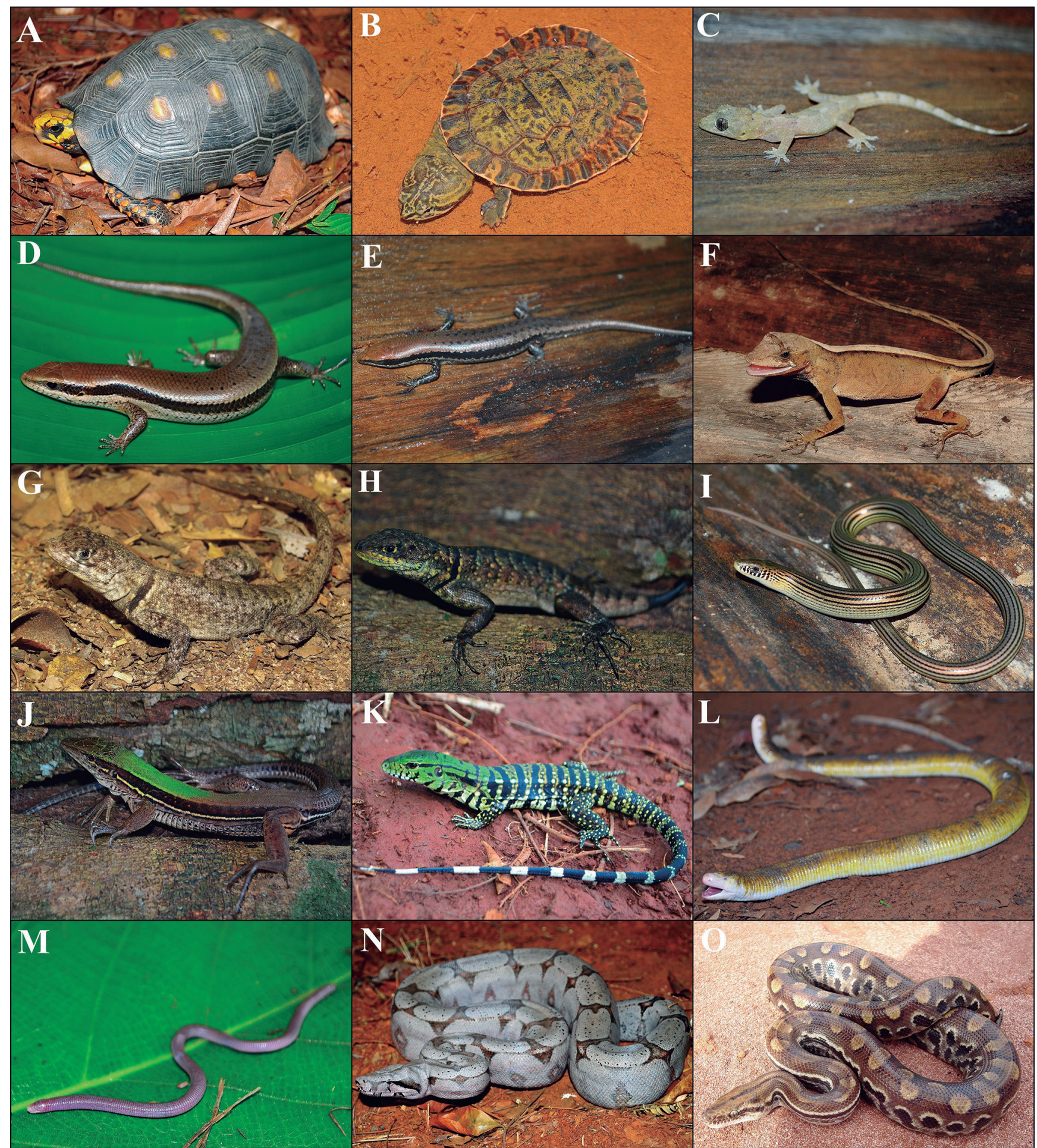

Figure 5. Species of reptiles recorded in Parque Estadual Altamiro de Moura Pacheco, state of Goiás, central Brazil: (A) Chelonoidis carbonarius, (B) Phrynops geoffroanus, (C) Hemidactylus mabouia, (D) Copeoglossum nigropunctatum, (E) Notomabuya frenata, (F) Norops brasiliensis, (G) Tropidurus oreadicus, (H) Tropidurus torquatus, (I) Ophiodes aff. striatus, (J) Ameiva ameiva ameiva, (K) Salvator merianae, (L) Amphisbaena alba, (M) Amphisbaena anaemariae, (N) Boa constrictor amarali, (0) Epicrates crassus.

sus, Apostolepis albicollaris, Oxyrhopus petolarius digitalis). The snake Erythrolamprus reginae macrosoma was also always associated to sites with waterbodies. By contrast, open environments had lower richness and few exclusive species, such as Amphisbaena alba, Sibynomorphus mikanii mikanii and Taeniophallus occipitalis. This pattern of segregated distribution is well known for the Cerrado biome (Nogueira et al., 2009), and demonstrates the lim- itations that open and forest environments represent for the distributions of reptiles.

Most reptile species recorded (72\%) have wide distributions among Brazilian biomes, while one lizard (Norops brasiliensis), three snakes (E. crassus, A. albicolaris and Bothrops moojeni) and one amphisbaenid (A. anaemariae) are endemic to the Cerrado. Despite being classified as a Cerrado endemic (Nogueira et al., 


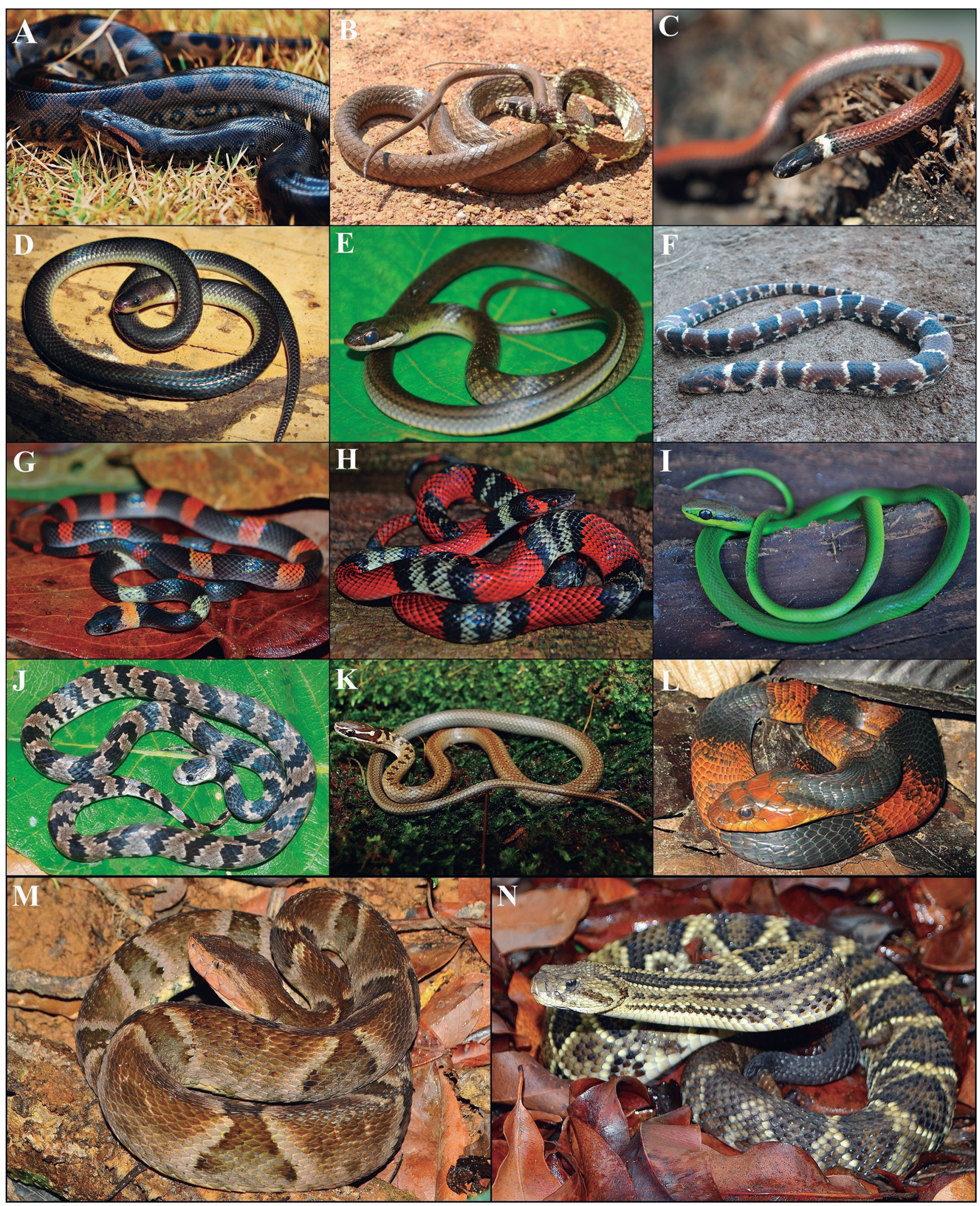

Figure 6. Species of reptiles recorded in Parque Estadual Altamiro de Moura Pacheco, state of Goiás, central Brazil: (A) Eunectes murinus, (B) Spilotes pullatus pullatus, (C) Apostolepis albicollares, (D) Atractus albuquerquei, (E) Erythrolamprus reginae macrosoma, (F) Hydrodynastes gigas, (G) Oxyrhopus petolarius digitalis, (H) Oxyrhopus guibei, (I) Philodryas olfersii, (J) Sibynomorphus mikanii mikanii, (K) Taeniophallus occipitalis, (L) Xenodon merremii, (M) Bothrops moojeni, (N) Crotalus durissus collilineatus (Photo "F" by D. Lopes).

2011), the snake A. albuquerquei should be considered as having wide distribution due to recent records in the Amazon (França et al., 2017). The number of endemic squamate reptiles recorded for PEAMP can be consid- ered low relative to the high levels expected in regions of open high plateaus (Nogueira et al., 2011). None of the reptile species recorded are considered at any level of threat. 
As one of the last protected areas of seasonal semi-deciduous forest of the Cerrado, PEAMP is very important for biodiversity conservation. The anuran and reptile richness found is regionally representative, with communities typical of forest environments. The communities are composed by endemic species that are mainly adapted to forest areas, habitat-specific and with restricted distributions, and thus are in need of more research efforts to obtain information on geographic distribution, ecology and natural history. Furthermore, since approximately $50 \%$ of the points sampled during the present study were flooded during the filling of the João Leite reservoir, the data presented here will be valuable to any future research that assesses the impact of the insertion of the reservoir on the local herpetofauna.

\section{ACKNOWLEDGEMENTS}

We thank Leandro Baiocchi, Ivan Tibúrcio, Mônica R. Silva, Rafael Filgueira Jorge, Rhuâna T. Nascimento, Tarcilla Valtuille, Geanice Cristina and other undergraduate students for assistance during field work; Coordenação de Aperfeiçoamento de Pessoal de Nível Superior (CAPES) for providing scholarship to VG and WPR; and Fundação de Amparo à Pesquisa do Estado de São Paulo (FAPESP) for providing scholarship to DPFF. Erick Wild reviewed the English language.

\section{REFERENCES}

Ab'Sáber, N.A. 1983. 0 domínio dos cerrados: introdução ao conhecimento. Revista do Serviço Público, 111(4): 41-55.

Bensusan, N. 2006. Conservação da biodiversidade em áreas protegidas. Rio de Janeiro, Editora FGV.

Beuchle, R.; Grecchi, R.C.; Shimabukuro, Y.E.; Seliger, R.; Eva, H.D.; Sano, E. \& Achard, F. 2015. Land cover changes in the Brazilian Cerrado and Caatinga biomes from 1990 to 2010 based on a systematic remote sensing sampling approach. Applied Geography, 58: 116-127.

Brasil. 2018. Instituto Nacional de Meteorologia. Ministério da Agricultura, Pecuária e Abastecimento, MAPA. Available at: http://www.inmet.gov. br/portal. Access in: 05/01/2018.

Brasileiro, C.A. \& Haddad, C.F.B. 2015. A New Species of Physalaemus from Central Brazil (Anura: Leptodactylidae). Herpetologica, 71(4): 280-288.

Cadle, J.E. \& Greene, H.W. 1993. Phylogenetic patterns, biogeography, and the ecological structure of Neotropical Snake assemblages. In: Ricklefs, R.E. \& Schluter, D. (Eds.). Species diversity in ecological communities: historical and geographical perspectives. Chicago, University of Chicago Press. p. 281-293.

Campos, A.C. \& Batista, V.M. 2010. Sistema biogeográfico do Cerrado goiano: 0 Parque Ecológico Altamiro de Moura Pacheco. In: Congresso Brasileiro de Gestão Ambiental, $1^{\circ}$. Anais. Bauru, Instituto Brasileiro de Estudos Ambientais. Disponível em: http://www.ibeas.org.br/congresso/ Trabalhos2010/XI-019.pdf.

Campos, F.S. \& Vaz-Silva, W. 2010. Distribuição espacial e temporal da anurofauna em diferentes ambientes no município de Hidrolândia, G0, Brasil Central. Neotropical Biology \& Conservation, 5(3): 179-187.

Costa, G.C.; Nogueira, C.; Machado, R.B. \& Colli, G.R. 2007. Squamate richness in the Brazilian Cerrado and its environmental-climatic associations. Diversity and Distributions, 13(6): 714-724.
Costa, H.C. \& Bérnils, R.S. 2018. Répteis do Brasil e suas Unidades Federativas: Lista de espécies. Herpetologia Brasileira, 8(1): 11-57.

Dória, T.A.F.; Klein, W.; Abreu, R.0.; Santos, D.C.; Cordeiro, M.C.; Silva, L.M.; Bonfim, V.M.G. \& Napoli, M.F. 2015. Environmental variables Influence the composition of Frog communities in riparian and semi-deciduous forests of the Brazilian Cerrado. South American Journal of Herpetology, 10(2): 90-103.

Duellman, W.E. 1999. Distribution Patterns of Amphibians in South America. In:Duellman, W.E. (Ed.). Patterns of distribution of amphibians. Baltimore, The Johns Hopkins University Press. p. 255-327.

França, D.P.F.; Freitas, M.A.; Ramalho, W.P. \& Bernarde, P.S. 2017. Diversidade local e influência da sazonalidade sobre taxocenoses de anfíbios e répteis na Reserva Extrativista Chico Mendes, Acre, Brasil. Iheringia Série Zoologia, 107: e2017023.

França, F.G.R. \& Braz, V.S. 2013. Diversity, activity patterns, and habitat use of the snake fauna of Chapada dos Veadeiros National Park in Central Brazil. Biota Neotropica, 13(1): 74-85.

Françoso, R.D.; Brandão, R.; Nogueira, C.C.; Salmona, Y.B.; Machado, R.B. \& Colli, G. 2015. Habitat loss and the effectiveness of protected areas in the Cerrado Biodiversity Hotspot. Natureza \& Conservação, 13(1): 35-40.

Frost, D.R. 2018. Amphibian Species of the World: an Online Reference. Version 6.0. Available at: http://research.amnh.org/herpetology/ amphibia/index.html. Access in: 31/10/2018.

Gambale, P.G.; Woitovicz-Cardoso, M.; Vieira, R.R.; Batista, V.G.; Ramos, J. \& Bastos, R.P. 2014. Composição e riqueza de anfíbios anuros em remanescentes de Cerrado do Brasil Central. Iheringia Série Zoologia, 104(1): 50-58.

Guerra, V.; Llusia, D.; Gambale, P.G.; Morais, A.R.; Márquez, R. \& Bastos, R.P. 2018. The advertisement calls of Brazilian anurans: Historical review, current knowledge and future directions. PLOS ONE, 13(1): e0191691.

Heyer, W.R.; Donnelly, M.A.; McDiarmid, R.W.; Hayek, L.C. \& Foster, M.S. 1994. Measuring and monitoring biological diversity. Standard methods for Amphibians. Washington, Smithsonian Institution Press.

IUCN - International Union for the Conservation of Nature. 2017. The IUCN Red List of Threatened Species. Version 2017-3. Available at: http://www. iucnredlist.org. Access in: 05/01/2018.

Kopp, K.; Signorelli, L. \& Bastos, R.P. 2010. Distribuiç̧ão temporal e diversidade de modos reprodutivos de anfíbios anuros no Parque Nacional das Emas e entorno, estado de Goiás, Brasil. Iheringia Série Zoologia, 100(3): 192-200.

Luque, S.; Santiago, S. \& Fortin, M. 2012. Landscape connectivity analysis for conservation: insights from combining new methods with ecological and genetic data. Landscape Ecology, 27(2): 153-157.

Lynch, J.D. 2005. Discovery of the richest frog fauna in the world - an exploration of the forests to the North of Leticia. Revista de la Academia Colombiana de Ciencias Exacta, Físicas y Naturales, 29(113): 581-588.

Melo, M.; Fava, F.; Pinto, H.B.A.; Bastos, R.P. \& Nomura, F. 2013. Diversidade de Anuros (Amphibia) na reserva extrativista Lago do Cedro e seu entorno, Aruanã, Goiás. Biota Neotropica, 13(2): 205-217.

Mittermeier, R.A.; Robles, G.P.; Hoffmann, M.; Pilgrim, J.; Brook, S.T.; Mittermeier, C.G.; Lamoreux, J. \& Da Fonseca, G.A.B. 2004. Hotspots Revisited. Mexico City, CEMEX.

Morais, A.R.; Bastos, R.P.; Vieira, R. \& Signorelli, L. 2012. Herpetofauna da Floresta Nacional de Silvânia, um remanescente de Cerrado no Brasil Central. Neotropical Biology and Conservation, 7(2): 114-121.

Morais, A.R.; Oliveira, S.R.; Maciel, N.M.; Zórtea, M.; Silva, D.A.; Vaz-Silva, W. \& Lima-Ribeiro, M.S. 2018. New records of Rhinella sebbeni Vaz-Silva, Maciel, Bastos and Pombal Jr. 2015 (Anura: Bufonidae) and a predictive distribution map based on ecological niche model. Herpetology Notes, 11: 197-199. 
Moura, J.U. \& Bucci, R.L.F. 1981. Aspectos geográficos das micro-regiões do Mato Grosso de Goiás, Meia Ponte, sudeste goiano e planalto goiano. Boletim Goiano de Geografia, 1(2): 61-94.

Nogueira, C.; Colli, G.R. \& Martins, M. 2009. Local richness and distribution of the lizard fauna in natural habitat mosaic of the Brazilian Cerrado. Austral Ecology, 34: 83-96.

Nogueira, C.; Ribeiro, S.; Costa, G.C. \& Colli, G.R. 2011. Vicariance and endemism in a Neotropical savanna hotspot: Distribution patterns of Cerrado squamate reptiles. Journal of Biogeography, 38(10): 1907-1922.

Nogueira, C.; Valdujo, P.H. \& França, F.G.R. 2005. Habitat variation and lizard diversity in a Cerrado area of Central Brazil. Studies on Neotropical Fauna and Environment, 40(2): 105-112.

Oda, F.H.; Ávila, R.W.; Drummond, L.0.; Santos, D.L.; Gambale, P.G.; Guerra, V.; Vieira, R.R.; Vasconcelos, T.S.; Bastos, R.P. \& Nomura, F. 2017. Reptile surveys reveal high species richness in areas recovering from mining activity in the Brazilian Cerrado. Biologia, 72(10): 1194-1210.

Paiva, R.J.0.; Brites, R.S. \& Machado, R.B. 2015. The role of protected areas in the avoidance of anthropogenic conversion in a high pressure region: a matching method analysis in the core region of the Brazilian Cerrado. PLOS ONE, 10(7): e0132582.

Peel, M.C.; Finlayson, B.L. \& McMahon, T.A. 2007. Updated world map of the Köppen-Geiger climate classification. Hydrology and Earth System Sciences, 11: 1633-1644.

Ramalho, W.P.; Batista, V.G. \& Lozi, L.R.P. 2014. Anfíbios e répteis do médio rio Aporé, estados de Mato Grosso do Sul e Goiás, Brasil. Neotropical Biology and Conservation, 9(3): 147-160.

Recoder, R.S. \& Nogueira, C. 2007. Composição e diversidade de Répteis Squamata na região sul do Parque Nacional Grande Sertão Veredas, Brasil Central. Biota Neotropica, 7(3): 267-278.

Recoder, R.S.; Teixeira Junior, M.; Camacho, A.; Nunes, P.M.S.; Mott, T.; Valdujo, P.H.; Ghellere, J.M.; Nogueira, C. \& Rodrigues, M.T. 2011. Répteis da Estação Ecológica Serra Geral do Tocantins, Brasil Central. Biota Neotropica, 11(1): 263-281.

Ribeiro, J.F. \& Walter, B.M.T. 1998. Fitofisionomias do Bioma Cerrado. In: Sano, S.M. \& Almeida, S.P. (Eds.). Cerrado: Ambiente e Flora. Planaltina, Embrapa-CPAC. p. 89-166.

Ribeiro-Júnior, M.A.; Rossi, R.V.; Miranda, C.L. \& Ávila-Pires, T.C.S. 2011. Influence of pitfall trap size and design on herpetofauna and small mammal studies in Neotropical Forest. Zoologia, 28: 80-91.
Rios, C.H.V.; Novelli, I.A.; Hudson, A.A.; Cozendey, P.; Lima, L.C. \& Sousa, B.M. 2017. Communities and occurrences of Squamata reptiles in different vegetation types of the Serra de São José, Minas Gerais, Brazil. Biota Neotropica, 17(1): e20150103.

Santoro, G.R.C.C. \& Brandão, R.A. 2014. Reproductive modes, habitat use, and richness of anurans from Chapada dos Veadeiros, central Brazil. NorthWestern Journal of Zoology, 10(2): 365-373.

Santos, D.L.; Andrade, S.P.; Victor-Jr., E.P. \& Vaz-Silva, W. 2014. Amphibians and reptiles from southeastern Goiás, Central Brazil. Check List, 10: 131-148.

Silva, J.F.; Fariñas, M.R.; Felfili, J.M. \& Klink, C.A. 2006. Spatial heterogeneity, land use and conservation in the Cerrado region of Brazil. Journal of Biogeography, 33(3): 536-548.

Uetz, P.; Freed, P. \& Hošek, J. 2018. The Reptile Database. Available at: http:// www.reptile-database.org. Access in: 25/02/2018.

Valdujo, P.H.; Nogueira, C.C.; Baumgarten, L.; Rodrigues, F.H.G.; Brandão, R.A.; Eterovic, A.; Ramos-Neto, M.B. \& Marques, O.A.V. 2009. Squamate Reptiles from Parque Nacional das Emas and surroundings, Cerrado of Central Brazil. Check List, 5(3): 405-417.

Valdujo, P.H.; Silvano, D.L.; Colli, G. \& Martins, M. 2012. Anuran species composition and distribution patterns in Brazilian Cerrado, a neotropical hotspot. South American Journal of Herpetology, 7(2): 63-78.

Vasconcelos, T.S.; Prado, V.H.M.; da Silva, F.R. \& Haddad, C.F.B. 2014. Biogeographic distribution patterns and their correlates in the diverse frog fauna of the Atlantic Forest Hotspot. PLOS ONE, 9(8): e104130.

Vaz-Silva, W.; Maciel, N.M.; Bastos, R.P. \& Pombal Jr., J.P. 2015. Revealing two new species of the Rhinella margaritifera species group (anura, bufonidae): an enigmatic taxonomic group of neotropical toads. Herpetologica, 71(3): 212-222.

Vidal, N.; Dewynter, M. \& Gower, D.J. 2010. Dissecting the major American snake radiation: A molecular phylogeny of the Dipsadidae Bonaparte (Serpentes, Caenophidia). Comptes Rendus Biologies, 333(1): 48-55.

Wiens, J.J.; Pyron, R.A. \& Moen, D.S. 2011. Phylogenetic origins of local-scale diversity patterns and the causes of Amazonian megadiversity. Ecology Letters, 14(7): 643-652.

\section{APPENDIX 1}

Vouchers specimens were deposited in the Coleção Zoológica da Universidade Federal de Goiás (ZUFG) and Centro de Estudos e Pesquisas Biológicas (CEPB) of the Pontifícia Universidade Católica de Goiás. Amphibians: Adenomera aff hylaedactyla:ZUFG-11098; Barycholos ternetzi:ZUFG-2186;ZUFG-3187;ZUFG-3199. Boana albopunctata:ZUFG-4027. Boana paranaiba:ZUFG-3252. Chiasmocleis albopunctata: ZUFG-3192; ZUFG-3193; ZUFG-3194; ZUFG-3195. Dermatonotus muelleri: ZUFG-11103. Elachistocleis cesarii: ZUFG-11102. Leptodactylus mystaceus: ZUFG-3196; ZUFG-3202. Leptodactylus mystacinus: ZUFG-3200; ZUFG-3201. Odontophrynus cultripes: ZUFG-3198. Physalaemus atim: ZUFG-11099. Physalaemus centralis: ZUFG-3197. Physalaemus cuvieri: ZUFG-3249; ZUFG-3250; ZUFG-3251. Physalaemus nattereri: ZUFG-11100. Pithecopus hypochondrialis: ZUFG-3205. Proceratophrys goyana: ZUFG-3204. Pseudopaludicola facureae: ZUFG-11101. Rhinella sebbeni: ZUFG-3190; 3191; ZUFG-3203; ZUFG-3246. Scinax constrictus: ZUFG-3243; ZUFG-3244; ZUFG-3245; ZUFG-3247; ZUFG-3248. Reptiles: Ameiva ameiva ameiva: ZUFG-1258. Amphisbaena anaemariae: CEPB-1838. Atractus alburquerquei: CEPB-8793. Bothrops moojenii: ZUFG-1247. Copeoglossum nigropunctatum: ZUFG-1255. Norops brasiliensis: ZUFG-1256. Notomabuya frenata: ZUFG-1245. Oxyrhopus trigeminus: ZUFG-1241. Oxyrhopus guibei: ZUFG-1260. Oxyrhopus petolarius digitalis: ZUFG-1246. Philodryas olfersii: ZUFG-1261. Salvator merianae: ZUFG-1259. Sibynomorphus mikanii mikanii: ZUFG-1244. Tropidurus torquatus: ZUFG-1257. 